\title{
EFFECT OF INHIBITORS ON SYNTHESIS OF FATTY ACYL CHAINS PRESENT IN WAXES ON DEVELOPING MAIZE LEAVES
}

\author{
by \\ PINAROSA AVATO ${ }^{1,2}$, JØRN DALGAARD MIKKELSEN ${ }^{1}$ and \\ PENNY VON WETTSTEIN-KNOWLES ${ }^{1,3}$ \\ I Department of Physiology. Carlsberg Laboratory, \\ Gamle Carlsberg Vej 10, DK-2500 Copenhagen Valby \\ 2Istituto di Chimica Organica, Università di Pavia, \\ Viale Taramelli 10, I-27100 Pavia. Italy \\ ${ }^{3}$ Institute of Genetics, University of Copenhagen, \\ Øster Farimagsgade 2A, DK-1353 Copenhagen K
}

Keywords: Triallate, trichloroacetic acid, light, alkanes, primary alcohols, epicuticular, elongation systems

Free fatty acids were identified as the fifth lipid class in wax from green leaf segments. They were not isolatable from the wax on yellow leaf segments, which also lacked aldehydes and appeared to have more esters and alkanes than primary alcohols. The chain length spectra of the alkanes and both ester moieties from yellow tissue are distinguishable from those of green tissue by the prominent amounts of shorter homologues, but the homologue distributions of the aldehydes and primary alcohols from the two types of tissue were similar. Tissue slices from yellow leaf segments incorporated $8.7 \%$ of the ${ }^{14} \mathrm{C}$ into wax lipids, whereas those from green segments were only half as efficient. In all wax fractions shorter homologues contained relatively more ${ }^{14} \mathrm{C}$ if they came from wax synthesized by yellow rather than green tissue. In wax from green tissue slices, $75 \%$ of the ${ }^{14} \mathrm{C}$ was in 32 carbon chains compared to $29 \%$ in that from yellow tissue slices. Pre-treatment of green tissue slices with $2.5 \mu \mathrm{mol}$ of $\mathrm{Cl}_{3} \mathrm{AcONa}$ inhibited total wax synthesis by $49 \%$, primarily via blocking synthesis of $\mathrm{C}_{32}$ chains. While pre-treatment of yellow tissue slices with $2.5 \mu \mathrm{mol}$ of triallate inhibited total wax synthesis by only $10 \%, \mathrm{C}_{32}$ chain synthesis was reduced by $2,600 \mathrm{pmol}(41 \%)$. In contrast to the $\mathrm{Cl}_{3} \mathrm{AcONa}$ inhibition, this reduction was to a large extent $(1,700 \mathrm{pmol})$ compensated for by increases in $\mathrm{C}_{28}$ and $\mathrm{C}_{30}$ chain synthesis.

\footnotetext{
Abbreviations: Avedex $=\mathrm{S}-\left(2,3\right.$-dichloroallyl)diisopropylthiocarbamate; $\mathrm{Cl}_{3} \mathrm{AcONa}=$ trichloroacetic acid sodium salt; $\mathrm{cpm}=$ counts per minute; $\mathrm{DEPH}=$ di-2-ethylhexylphthalate; $\mathrm{EPTC}=\mathrm{S}$-ethyldipropylthiocarbamate; $\mathrm{GLC}=$ gas liquid chromatography; $\mathrm{MS}=$ mass spectrometry; $\mathrm{TLC}=$ thin layer chromatography; triallate $=\mathrm{S}-(2,3,3$,-trichloroallyl)diisopropylthiocarbamate.
} 


\section{INTRODUCTION}

Alkanes, esters, aldehydes and primary alcohols are among the lipids found in epicuticular waxes of maize leaves $(2,6)$. Synthesis of these long chain lipids by the epidermal cells presumably occurs as follows (see 41 ): $\mathrm{C}_{16}$ fatty acids are elongated to specific chain lengths by the addition of $\mathrm{C}_{2}$-units from malonyl-CoA. The elongated fatty acyl chains are (i) decarboxylated to give alkanes $\left(\mathrm{C}_{31}, \mathrm{C}_{29}\right.$ and $\mathrm{C}_{27}$, in order of decreasing importance), or (ii) reduced to aldehydes and primary alcohols (predominantly $\mathrm{C}_{32}$ ). Certain of the latter are esterified to yield esters. The existence of two elongation-decarboxylation complexes has been inferred recently from a comparison of the wax composition on the leaves of glossy mutants $(2,6)$. Experimental results from other plants have shown that more than one elongation system (parallel or sequential) can be involved in production of the long wax fatty acyl chains (see 41). Inhibitors were one of the useful tools in the studies leading to these conclusions. Some environmental parameters are also able to modify the specific chain lengths characterizing a wax class. For example, the chain length composition of the wax lipid classes on barley seedling leaves depends on whether they are grown in the light or dark (11).

During differentiation of a maize leaf the yellow, tightly coiled tissue emerges from its encasement by the next older leaf and becomes green in the light. The composition of waxes from the yellow and green leaf segments of a developing leaf were found to be different. Therefore, we exploited this normal developmental process to learn more about the elongation mechanism(s) involved in wax synthesis. The ability of tissue slices from the two tissue types to incorporate $\left[1-{ }^{14} \mathrm{C}\right]$-acetate into wax lipids was studied, and the distribution of the total wax fatty acyl chains synthesized determined. Preincubations of the tissue slices with the thiocarbamate triallate or the sodium salt of trichloroacetic acid had interesting effects on their capabilities to elongate fatty acyl chains.

\section{MATERIALS AND METHODS}

Seeds of wild type maize (Zea mays L.) inbred strain WF9 were planted in a unity soil (clay:sphagnum; w/w; W. Platin \& Co., Swe- den) and grown in a model WE-95 Percival growth chamber under continuous light $(8,500$ lux). The thermoperiodicity was 16 hours at $25^{\circ} \mathrm{C}$ and 8 hours at $20^{\circ} \mathrm{C}$ with a relative humidity of $80 \%$. The green leaves used for analyses of the wax composition were harvested from plants when approximately half of the eighth leaf blade was emerged. The epicuticular waxes were collected (39) from the fifth, sixth or seventh leaves of these plants. Somewhat younger plants on which the sixth leaf was only five to ten $\mathrm{cm}$ emerged ( 22 days after planting) were used for the other studies. That is, the fifth leaf on these plants was divided into three parts (i) the yellow, still tightly coiled basal third, (ii) the green, but not completely expanded tip half and (iii) the intervening segment which was discarded. The yellow leaf tissue (i) minus the basal $5 \mathrm{~cm}$ was used both in analyses of the extractable wax composition and in incorporation and inhibitor experiments. The green leaf tissue (ii) minus the terminal ten $\mathrm{cm}$ was used for incorporation and inhibitor experiments.

To prepare tissue slices for the incorporation and inhibitor studies, the leaf segments were cut into $0.5 \times 2 \mathrm{~mm}$ slices with a razor blade. In our initial studies tissue slices were prepared and weighed individually for each experiment forming a concentration series. The somewhat variable results observed in the distribution of label among the lipid classes were attributed to the variation in the amount of tissue used. This problem was overcome by preparing a large enough amount of tissue slices so that equal sized aliquots could be weighed out for each experiment within a concentration series. In the results reported using green tissue slices and $\mathrm{Cl}_{3} \mathrm{AcONa}$ (Merck, Darmstadt, West Germany), a $1.5 \mathrm{~g}$ aliquot was used in each experiment, while in those using yellow tissue slices and triallate, $2 \mathrm{~g}$ aliquots were used. In the study with green tissue slices and triallate, $2.6 \mathrm{~g}$ was used for the control, $2.0 \mathrm{~g}$ for the $0.25 \mu \mathrm{mol}$ experiment and $2.4 \mathrm{~g}$ for the $2.5 \mu \mathrm{mol}$ experiment. Immediately after weighing, the tissue slices were transferred to a glass stoppered $100 \mathrm{ml}$ erlenmeyer flask containing water with or without a specified amount of inhibitor. The $\mathrm{Cl}_{3} \mathrm{AcONa}$ was dissolved and the triallate dispersed in water by sonicating (34), after which appropriate dilution series of the two inhibitors were prepared. 
The flasks containing the tissue slices were placed in a shaking water bath at $22-23^{\circ} \mathrm{C}$ under light supplied by two Osram-L-Fluora Model L20W/77 lamps (1,350 lux). After a 30 min pre-incubation, $0.258 \mu \mathrm{mol}(15.2 \mu \mathrm{Ci}, 59$ $\left.\mathrm{mCi} \cdot \mathrm{mmol}^{-1}\right)$ of sodium $\left[1-{ }^{14} \mathrm{C}\right]$-acetate (The Radiochemical Centre, Amersham, England) was added which brought the final volume of liquid to $10 \mathrm{ml}$. Three hours later the epicuticular waxes were recovered (33).

Preparative thin layer chromatography (TLC) or preparative radio-TLC on silica gel $\mathrm{H}$ plates was used to isolate the wax classes as follows: hexane was employed as the first developing solvent to separate the hydrocarbons from the other wax classes, while either amylene stabilized chloroform or benzene was used as the second developing solvent to separate the esters, aldehydes, primary alcohols and free fatty acids (43). The lipid classes were located and eluted from the gel as detailed earlier (32). Described procedures for the quantitation of the radioactivity in the various lipids by liquid scintillation were followed (34). In the compositional studies free fatty acids were separated from the wax by trapping them in a $10 \% \mathrm{NaOH}$-Gas Chrome Q column (40) before carrying out the preparative TLC.

For the compositional studies the isolated and purified lipid classes and/or their derivatives (33, 39) were subjected to gas liquid chromatography (GLC) using the instrument, columns and conditions specified previously (43). Standards were used for chain length identification (39). GLC-mass spectrometry (MS) was carried out to confirm the identification of (i) yellow leaf alkanes $\mathrm{C}_{23}, \mathrm{C}_{25}, \mathrm{C}_{27}, \mathrm{C}_{29}$ and $\mathrm{C}_{31}$, and (ii) green leaf free acids $\mathrm{C}_{20}$ to $\mathrm{C}_{32}$ inclusive. It was not possible to analyze the intact maize esters on SP-2 100 columns as the shorter barley esters can be (43). Instead, a 1\% Dexsil-300 column (91 $\mathrm{cm} \times 3.2 \mathrm{~mm}$ ) on $100 / 120$ mesh Supelcoport (Supelco, Penn., USA) was used. The esters were identified by co-GLC with barley esters and a $\mathrm{C}_{50}$ standard (synthesized by $\mathrm{P}$. Avato). The conclusions drawn were confirmed by subjecting the total esters to MS. Transmethylation of the maize esters was not complete in 24 hours as is

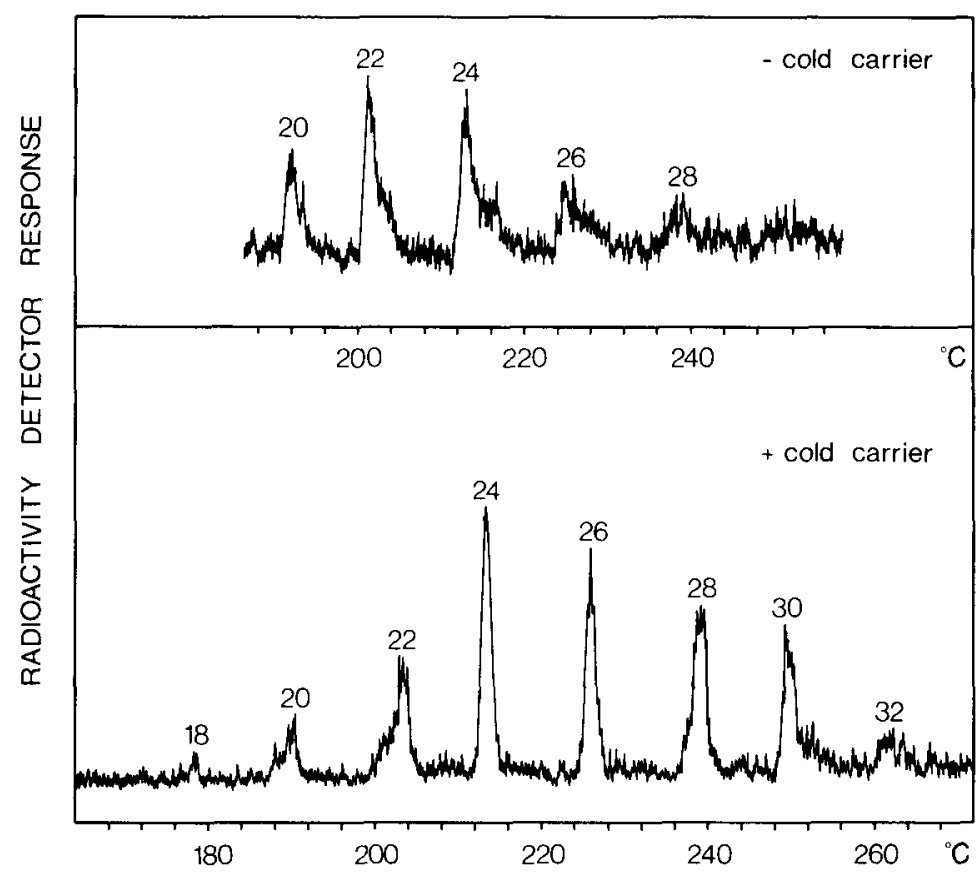

Figure 1. Radio-GLC patterns of the free fatty acid methyl esters isolated from yellow tissue slices which had been pre-incubated with $2.5 \mu \mathrm{mol}$ of triallate previous to (upper) and after (lower) the addition of cold carrier even chain length methyl esters having 18 to 28 carbon atoms.

The number above each peak represents the fatty acid chain length. 
that of the shorter barley esters (32). Therefore, at the end of the 24th hour, an additional aliquot of $14 \% \quad \mathrm{BF}_{3}-\mathrm{CH}_{3} \mathrm{OH}$ was added and the transesterification allowed to proceed an additional 2 hours at $80^{\circ} \mathrm{C}$. By this time the reaction was $95 \%$ or more completed as judged by the recovery of label in the resulting alcohols and fatty acid methyl esters.

On the basis of the radio-TLC analyses, inhibitor concentrations were selected that could be expected to reveal an effect of the inhibitor on the chain length distribution within a lipid class. Replicated experiments with the selected concentrations of inhibitors were then made so as to have enough sample for injection and analysis in the radio-GLC (33). The radio-TLC pattern of these replicated experiments was checked to verify that it was similar to the original results. For the green tissue slices five replicates were made with $2.5 \mu \mathrm{mol}$ of $\mathrm{Cl}_{3} \mathrm{AcONa}$, and for the yellow tissue slices two replicates each were made with 0.25 and $2.5 \mu \mathrm{mol}$ of triallate.

When small amounts of fatty acid methyl esters, less than $0.1 \mu \mathrm{g}$ per chain length, were injected into the radio-GLC, tailing of the radioactive peaks was sometimes observed as illustrated in Figure 1 upper. Gaussian shaped peaks could be obtained from the same sample if cold carrier methyl esters were co-injected as shown in Figure 1 lower. In the presently reported experiments, cold carrier was added when deemed necessary to the free or ester derived fatty acid methyl ester samples. This was especially necessary with samples from the yellow tissue slices. The actual carrier used per injection consisted of 10 or more $\mu \mathrm{g}$ of each of the methyl esters having 18 to 28 carbons. In Figure 1 lower some tailing of the longer chain lengths $\mathrm{C}_{30}$ and $\mathrm{C}_{32}$ is apparent, suggesting that it would have been better to add as cold carriers a mixture of all the potential chain lengths. Figure 2 demonstrates that 4 or more $\mu \mathrm{g}$ of each chain length is sufficient to give gaussian shaped peaks of all methyl esters with 16 or more carbons up to and including those with 32 carbons under our radio-GLC conditions. The actual $\mu \mathrm{gs}$ in each chain length as given in the text to Figure 2 were determined using the radio-GLC method described by NeTTING and BARR (36)

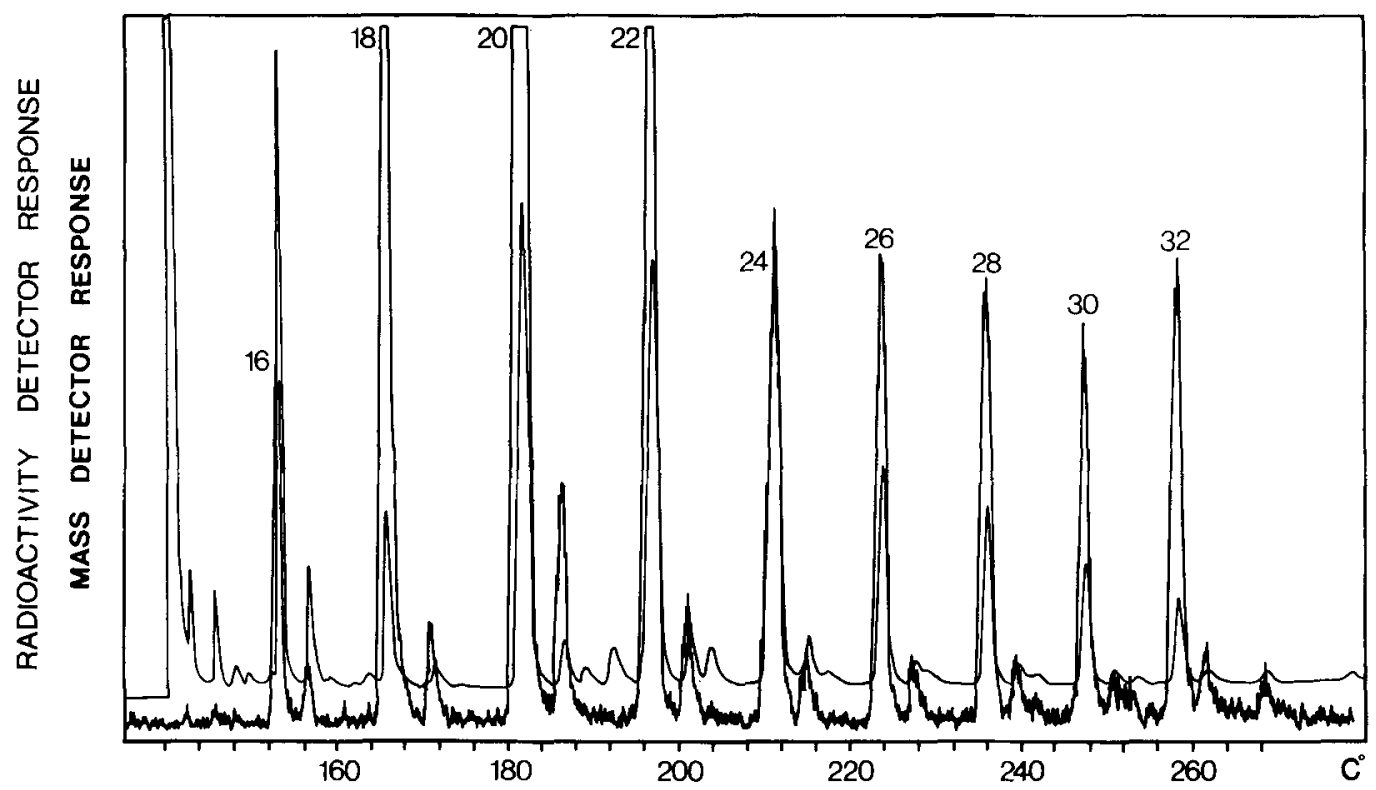

Figure 2. Radio and mass GLC patterns of free fatty acid methyl esters synthesized by whole barley spikes fed $[2-14 \mathrm{C}]$-acetate (32).

The number above each peak represents the fatty acid chain length. An homologous series of unknowns (probably branched fatty acids with odd numbers of carbon atoms) are eluted shortly after each of the even chain methyl esters. The mass in $\mu \mathrm{g}$ of each chain length is $\mathrm{C}_{16}, 10.9 ; \mathrm{C}_{18}, 5.9 ; \mathrm{C}_{20}, 16.2 ; \mathrm{C}_{22}, 16.0 ; \mathrm{C}_{24}, 17.3 ; \mathrm{C}_{26}$, $7.7 ; \mathrm{C}_{28}, 6.7 ; \mathrm{C}_{30}, 5.2 ; \mathrm{C}_{32}, 4.4$ (see section 2). The peaks contain 3,300 to $21,000 \mathrm{dpm}$. 


\section{RESULTS}

\subsection{Composition of the epicuticular wax at two developmental stages of maize leaves}

An examination of the waxes from the yellow and green segments revealed that they differed markedly in their lipid class composition. Primary alcohols dominated the wax from the green segments followed by the aldehydes and esters in good quantities plus a minor amount of alkanes. By contrast alkanes and esters were the largest components of the yellow wax. Primary alcohols were present, but no trace of aldehydes was visible with a Schiff's spray. Nevertheless trace amounts could be isolated from preparative plates. A distinct lipid staining spot was present at the origin in both waxes suggesting that free acids and/or other polar lipids were also present.

In the wax from the green leaf tissue, the $\mathrm{C}_{31}$ and $\mathrm{C}_{29}$ alkanes were the most important constituents (Table I), as expected (2). In the wax from the yellow tissue, the 31 and 33 homologues were reduced, in the example given in
Table I, from 58 to $6 \%$ by wt. of the total. This decrease was primarily compensated for by the appearance of the 21 and 23 homologues which amounted to $41 \%$ of the alkanes. Some variation in the distribution of the alkanes from the yellow tissue was noted from isolation to isolation, which presumably reflects small differences in the exact developmental stage of the leaf tissue. The chain length distribution of the alkanes from the wax on the yellow tissue bears no resemblance to that of any of the maize wax mutants hereto studied $(2,6)$. In the aldehydes and primary alcohols (analyzed as their acetate derivatives) of the waxes from both green and yellow tissue, the $\mathrm{C}_{32}$ homologue dominated; 84 to $97 \%$ by wt. (Table I). Three percent of the aldehydes from both tissues had a chain length of 34 carbons which has not been previously reported $(2,6)$. In the latter studies the $\mathrm{C}_{32}$ homologue accounted for at least $97 \%$ of both of these wax classes. The chain length composition of the primary alcohols from both leaf tissues

\section{Table I}

Distribution of normal chain lengths among six wax fractions isolated from green and yellow leaf tissue of maize (wt. \%).

\begin{tabular}{|c|c|c|c|c|c|c|c|c|c|c|c|}
\hline \multirow{2}{*}{$\begin{array}{l}\text { Chain } \\
\text { length }\end{array}$} & \multicolumn{2}{|c|}{ Alkanes } & \multicolumn{2}{|c|}{ Aldehydes } & \multicolumn{2}{|c|}{ Primary alcohols } & \multicolumn{2}{|c|}{ Ester alcohols } & \multicolumn{2}{|c|}{ Ester acids } & \multirow{2}{*}{$\begin{array}{c}\text { Free acidsal } \\
\text { Gr }\end{array}$} \\
\hline & Gr & Yel & $\mathrm{Gr}$ & Yel & $\mathrm{Gr}$ & Yel & $\mathrm{Gr}$ & Yel & $\mathrm{Gr}$ & Yel & \\
\hline 16 & & & & & & & & & 2.9 & 5.7 & 9.6 \\
\hline 18 & & & & & & & 1.9 & 3.1 & 2.7 & 8.1 & 4.3 \\
\hline 19 & & 3.6 & & & & & 0.3 & $\left.\operatorname{tr}^{b}\right)$ & $\operatorname{tr}$ & 0.8 & 0.2 \\
\hline 20 & & 2.1 & & & & & 12.7 & 17.8 & 14.4 & 32.2 & 3.1 \\
\hline 21 & & 17.0 & & & & & n.m.c) & n.m. & 0.5 & 1.3 & 0.5 \\
\hline 22 & & 1.9 & & & & & 6.6 & 12.8 & $25.4^{\mathrm{d})}$ & $31.9 \mathrm{~d})$ & $18.6^{\mathrm{d})}$ \\
\hline 23 & & 23.7 & & & & & 1.4 & 1.1 & 0.6 & 2.1 & 1.1 \\
\hline 24 & & 1.0 & & & & & 12.8 & 25.4 & 27.1 & 11.7 & 23.4 \\
\hline 25 & $(3.7 \mathrm{~d})$ & $10.8^{\mathrm{d})}$ & & & & & 0.8 & 0.6 & 0.7 & 0.6 & 2.1 \\
\hline 26 & & 0.7 & 0.8 & & & & 3.7 & 9.6 & 18.9 & 4.3 & 18.9 \\
\hline 27 & 5.2 & 12.6 & & & & & $\operatorname{tr}$ & $\operatorname{tr}$ & 0.2 & & 0.5 \\
\hline 28 & & 0.9 & 2.7 & & & & 0.3 & 0.8 & 4.5 & 0.6 & 5.6 \\
\hline 29 & 21.6 & 19.7 & 0.3 & & & & $\operatorname{tr}$ & $\operatorname{tr}$ & 0.2 & & 1.5 \\
\hline 30 & & 0.5 & 7.2 & 6.2 & 2.6 & 5.7 & 5.3 & 2.5 & 1.1 & 0.4 & 2.6 \\
\hline 31 & 42.0 & 5.3 & 0.8 & & & & 1.3 & 0.4 & & & 1.3 \\
\hline 32 & & 0.1 & 83.6 & 90.9 & 96.8 & 94.3 & 53.4 & 26.5 & 0.8 & 0.2 & 5.2 \\
\hline 33 & 16.4 & 0.4 & 1.1 & & & & $\operatorname{tr}$ & $\operatorname{tr}$ & & & 0.4 \\
\hline 34 & & & 3.4 & 2.9 & 0.6 & $\operatorname{tr}$ & tr & 0.3 & & & 1.1 \\
\hline 35 & 1.1 & & & & & & & & & & \\
\hline
\end{tabular}

a) Free acids were not isolatable from the yellow tissue (see section 3.1.).

b) $\operatorname{tr}=$ trace, $<0.5 \%$.

c) n.m. = not measurable minor component which may be contaminated by DEHP (43).

d) Amount may be slightly overestimated if contamination by DEHP occurred (43). 
and that of the alkanes from green leaf tissue when isolated from the different leaves is remarkably constant.

Free fatty acids have been positively identified in maize leaf wax for the first time, although only in that from the green leaf tissue. They were believed to be absent or if present to represent $1 \%$ or less of the wax. This conclusion was based on the failure to detect them on TLC plates $(2,3)$, and on the absence of diagnostic peaks for free acids in an infrared spectrum of whole wax (BIANCHI and Avato, unpubl.). In the present study the lipid class composition of the waxes was compared before and after passing them through a $\mathrm{NaOH}$ containing column. The lipids from the green tissue at the origin after TLC in benzene were absent after the wax had been passed through the column. Recovery of acidic lipids from the column, preparation of methyl ester derivatives and GLC gave results such as that shown in Table I. The most prominent fatty acids had 22, 24 and 26 carbons. Some variation in the distribution was noted from isolation to isolation. This is probably a reflection of the small amount of the free acids in the wax and their susceptibility to contamination, e.g., by phthalates (43). Although a distinct lipid staining spot at the origin was observed after TLC of the wax isolated from yellow tissue (42), no free acids were recoverable. In this case the lipid staining material must have been primarily other polar lipids, present in the wax extract because of the unavoidable contact of cut surfaces with the chloroform during isolation. Thus, we conclude that either free acids are not present in the yellow tissue wax or that they are present in too small an amount to be detected by the technique used.

The compositions of the ester acid and alcohol moieties, wt. \% as their methyl ester and acetate derivatives, respectively, are also shown in Table I. Surprisingly, the $\mathrm{C}_{32}$ ester alcohol accounted for only $53 \%$ of these moieties from the green leaf tissue. Previous studies had led us to expect that they should comprise 95 to $100 \%$ of the ester alcohols (2). The $\mathrm{C}_{26}, \mathrm{C}_{28}$ and $\mathrm{C}_{30}$ alcohols were only $9 \%$ of the mass, while the still shorter $\mathrm{C}_{20}$ and $\mathrm{C}_{24}$ alcohols amounted to $25 \%$. That the $\mathrm{C}_{22}$ alcohol is less important than the $\mathrm{C}_{20}$ and $\mathrm{C}_{24}$ alcohols is also characteristic for ester alcohols from five of the nine analyzed maize wax mutants $(2,6)$. In the yellow leaf tissue wax, the proportion of the $\mathrm{C}_{32}$ homologue among the ester alcohol moieties was even smaller; $27 \%$ of the total. The $\mathrm{C}_{20}, \mathrm{C}_{22}, \mathrm{C}_{24}$ and $\mathrm{C}_{26}$ chains were more prominent than they were in the ester alcohol spectrum from the green tissue wax. On the other hand, the distribution of ester acids from the green tissue bears a reasonable resemblance to that reported earlier $(2,6)$ with the most important chain length being $\mathrm{C}_{24}$ followed by $\mathrm{C}_{20}, \mathrm{C}_{22}$ and $\mathrm{C}_{26}$ in various orders of prominence. An analogous difference between the distributions of the ester alcohol moieties from the two tissues occurred between those of the ester acid moieties. That is, the ester acids of the yellow tissue were characterized by increased amounts of the shorter homologues $\left(\mathrm{C}_{20}\right.$ and $\left.\mathrm{C}_{22}\right)$ at the expense of the longer ones $\left(\mathrm{C}_{24}\right.$ and $\mathrm{C}_{26}$ ). Interestingly, the distribution of both ester acid and alcohol moieties from the yellow tissue wax resembles that reported for these lipids from the mutants $g l-5,-8$ and $-18(5,6)$.

To verify that the relatively small amount of $\mathrm{C}_{32}$ ester alcohols in the green tissue was not due to experimental error, intact esters were examined from both types of tissue. A GLC separation of maize wax esters from green leaf tissue is shown in Figure 3. Although it is not possible to accurately measure the amounts of the various chain lengths because of tailing, it is obvious that two groups of esters occur; namely, those having 40 to 48 carbons and those having 52 to 58 carbons. The shorter esters are those expected if the $\mathrm{C}_{20}$ and $\mathrm{C}_{24}$ alcohols (Table I, column 7) are

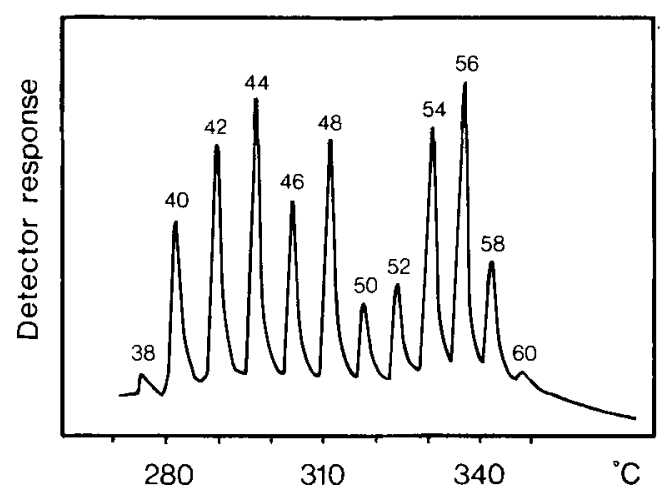

Figure 3. Separation of esters isolated from the wax of a green, fully emerged third maize leaf on a Dexsil-300 column, temperature programmed from 200 to $350^{\circ} \mathrm{C}$ at $3{ }^{\circ} \mathrm{C} \cdot \mathrm{min}^{-1}$. 

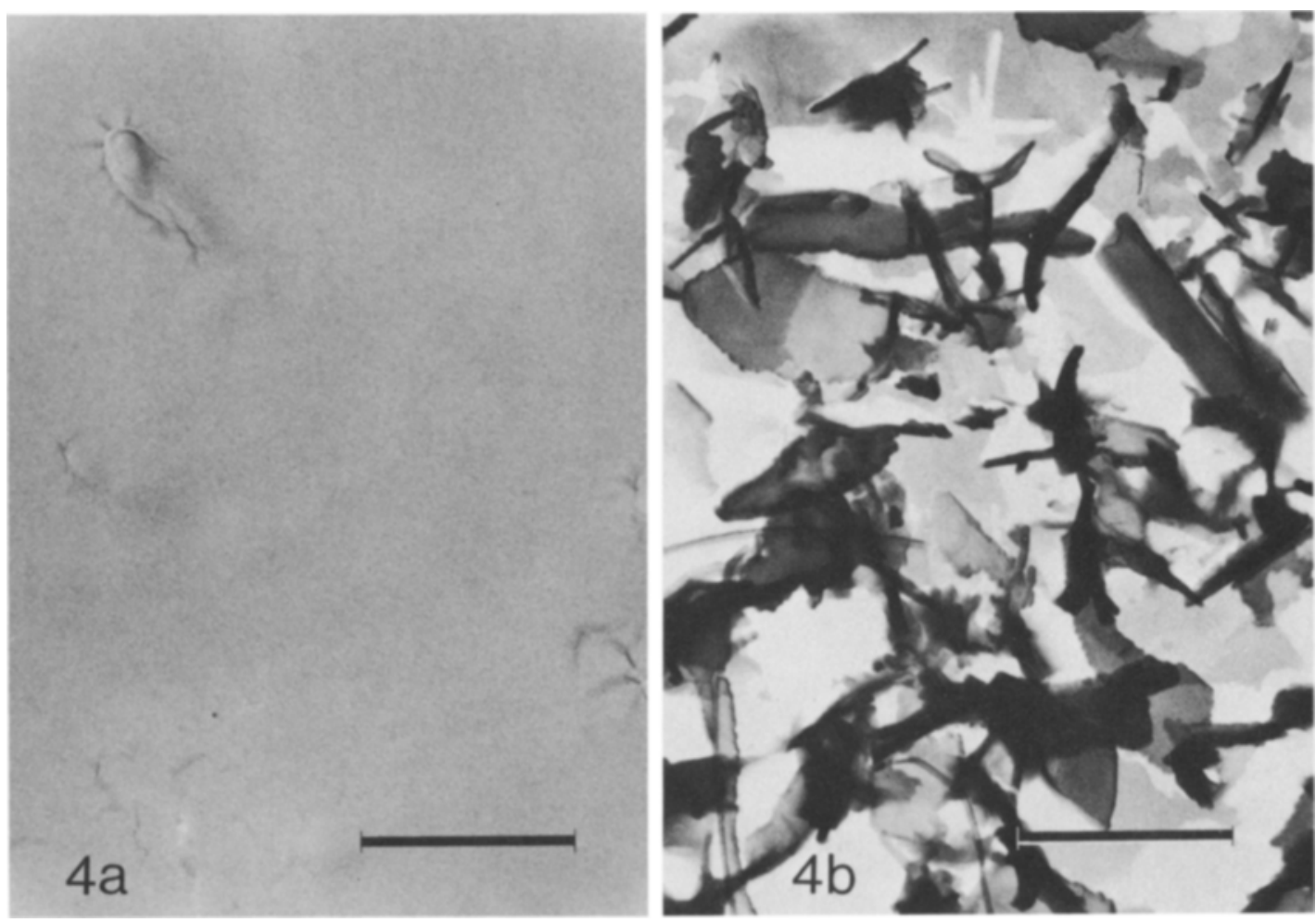

Figure 4. Platinum/carbon shadowed replicas (courtesy D. SIMPSON) of abaxial cuticular surfaces of yellow (a) and green (b) leaf tissue corresponding in developmental stages to those used in the incorporation experiments. $\times 23,000($ Bar $=1.0 \mu \mathrm{m})$.

esterified with the $\mathrm{C}_{20}, \mathrm{C}_{22}, \mathrm{C}_{24}$ and $\mathrm{C}_{26}$ acids (Table I, column 9), while the longer esters are the ones expected from esterification of the $\mathrm{C}_{32}$ alcohols (Table I, column 7) with the same four acids. The GLC separation of yellow tissue intact esters was characterized by the predicted relative increase of the $\mathrm{C}_{40}$ to $\mathrm{C}_{48}$ esters and decrease of the $\mathrm{C}_{52}$ and longer esters. When repeated ester isolations and analyses from different leaves of the two tissue types were carried out, the chain length distributions within each tissue type appeared very similar by visual inspection.

\subsection{Structure of wax on yellow and green leaf tissue}

Figure 4 illustrates the difference in the abaxial cuticular surfaces of the two types of leaf tissue. Most of the yellow leaf surface was characterized by the total absence of wax structures. Occasionally small apparently flat plates of the type illustrated in Figure 4a were observed. The surface of the green leaf tissue (Figure 4b) was well covered with the small plates typical of the structures on the abaxial surfaces of leaves whose waxes contain large amounts of primary alcohols $(9,17,37,39)$.

\subsection{Effects of trichloroacetate $\left(\mathrm{Cl}_{3} \mathrm{AcONa}\right)$ and triallate on incorporation of label into wax lipid classes by maize leaf tissue slices}

Tissue slices prepared from green leaf tissue incorporate most label from [1-14C]-acetate into the aldehydes (approx. $41 \%$ ), followed by the primary alcohols, fatty acids and esters (Table II). Only a small amount of label $(0.3 \%)$ is found in the alkanes. These results do not parallel the mass distribution of the wax lipids as has been visualized by TLC (see 42) or as has been 
Table II

Effects of pre-incubations with inhibitors on the incorporation of $[1-14 \mathrm{C}]$-acetate into the epicuticular wax classes by tissue slices from different parts of the fifth leaf of wild type maize.

\begin{tabular}{|c|c|c|c|c|c|c|c|c|c|}
\hline \multirow{2}{*}{$\begin{array}{l}\text { Leaf } \\
\text { tissue }\end{array}$} & \multirow{2}{*}{$\begin{array}{l}\text { Experimental } \\
\text { condition }\end{array}$} & \multirow[b]{2}{*}{$(\mu \mathrm{mol})$} & \multirow{2}{*}{$\begin{array}{l}\text { Total label } \\
\text { in wax }{ }^{\mathrm{a})} \\
\left(\mathrm{cpm} \times 10^{-5}\right)\end{array}$} & \multicolumn{6}{|c|}{ Wax class $\left.{ }^{b}\right)(\%$ of total cpm $)$} \\
\hline & & & & Alkanes & Esters & Aldehydes & $\begin{array}{c}\text { Un- } \\
\text { knownc) }\end{array}$ & $\begin{array}{l}\text { Primary } \\
\text { alcohols }\end{array}$ & $\begin{array}{l}\text { Fatty } \\
\text { acids }\end{array}$ \\
\hline \multirow[t]{8}{*}{ Green } & Control & & 13.9 & 0.3 & 11.8 & 45.0 & 0.9 & 27.1 & 14.9 \\
\hline & $\mathrm{Cl}_{3} \mathrm{AcONa}$ & $(0.50)$ & 15.0 & 0.5 & 15.2 & 39.5 & n.d.d) & 31.7 & 13.1 \\
\hline & & $(2.50)$ & 7.0 & 0.3 & 19.6 & 34.6 & n.d. & 28.7 & 16.8 \\
\hline & & $(5.00)$ & 6.2 & 0.4 & 21.5 & 31.8 & n.d. & 25.8 & 20.5 \\
\hline & & $(50.00)$ & 2.1 & 0.2 & 20.0 & 13.7 & 4.4 & 13.9 & 47.8 \\
\hline & Control & & 17.8 & 0.3 & 15.4 & 38.3 & n.d. & 26.7 & 19.3 \\
\hline & Triallate & $(0.25)$ & 12.6 & 0.3 & 13.1 & 38.4 & 2.5 & 21.2 & 24.5 \\
\hline & & $(2.50)$ & 2.7 & n.d. & 13.0 & 11.8 & n.d. & 7.0 & 68.2 \\
\hline \multirow[t]{4}{*}{ Yellow } & Control & & 27.2 & 2.0 & 31.5 & n.d. & n.d. & 41.8 & 24.7 \\
\hline & Triallate & $(0.25)$ & 26.4 & 2.4 & 31.1 & n.d. & n.d. & 31.9 & 34.6 \\
\hline & & $(2.50)$ & 24.5 & 1.8 & 30.5 & n.d. & n.d. & 35.2 & 32.5 \\
\hline & & $(25.00)$ & 6.4 & n.d. & 25.6 & n.d. & n.d. & 12.8 & 61.6 \\
\hline
\end{tabular}

a) Amount of label extracted by chloroform from a single experiment which is equivalent to total label in the epicuticular wax.

b) Details of the radio-TLC separation and quantitation procedures used are given in section 2 .

c) Minor lipid located between the aldehydes and primary alcohols when the lipid classes have been separated on silica gel $\mathrm{H}$ plates using benzene or chloroform.

d) n.d. = not detectable with the present methodology.

determined by column chromatography $(4,6)$. To illustrate, in such studies when wax was isolated from the entire intact plant of approx. the same age and of the same genotype, the primary alcohols have been reported to account for 62 to $63 \%$, the aldehydes for 9 to $20 \%$, the hydrocarbons or alkanes for 1 to $10 \%$ and the esters for 15 to $19 \%$ of the leaf wax. Such discrepencies between an in vivo mass distribution pattern and the incorporation pattern of tissue slices from the same leaves is not unusual.

When a half hour incubation of the green tissue slices with 2.5 or $5 \mu \mathrm{mol}$ of $\mathrm{Cl}_{3} \mathrm{AcONa}$ preceeded the addition of the $\left[1-{ }^{14} \mathrm{C}\right]$-acetate, total wax synthesis was reduced by 50 to $55 \%$ (Table II). No striking effect on the distribution of label among the wax classes occurred, although with 5 $\mu \mathrm{mol}$ of $\mathrm{Cl}_{3} \mathrm{AcONa}$ the amount of label in the aldehydes was only $32 \%$. Increasing the amount of $\mathrm{Cl}_{3} \mathrm{AcONa}$ to $50 \mu \mathrm{mol}$, however, led to a reduction of wax synthesis by $85 \%$, and to a significantly modified distribution pattern. The relative amount of label in the aldehydes and primary alcohols was decreased to $6 \%$ of that incorporated by the control, while the amount of label in the free acids was only reduced by $50 \%$.

Although the amounts of green leaf tissue varied somewhat in the triallate experiments, this does not appear to have influenced the obtained results. That is, the amount of label incorporated and especially the distribution of label among the wax classes was reasonably similar in the control and the $0.25 \mu \mathrm{mol}$ experiments (Table II) which involved the largest and smallest amounts of leaf tissue, respectively (see section 2). Pre-incubation with $2.5 \mu \mathrm{mol}$ of triallate, however, resulted in both an $85 \%$ decrease of label in the wax as well as a marked alteration in the distribution of label among the wax classes (Table II). Similar to the result with the greatest amount of $\mathrm{Cl}_{3} \mathrm{AcONa}$, the relative amount of label in the free acids was greatly increased and that in the primary alcohols and aldehydes was decreased. That blocking the 
synthesis of free acids requires higher concentrations than blocking that of other wax lipids has also been noted in whole spike inhibitor experiments in barley (32). In the distribution obtained with $2.5 \mu \mathrm{mol}$ of triallate, no label was detected in the alkanes although it was when $50 \mu \mathrm{mol}$ of $\mathrm{Cl}_{3} \mathrm{AcONa}$ were used.

The data in Table II also demonstrate that yellow leaf tissue slices are much more efficient in label incorporation from $\left[1-{ }^{14} \mathrm{C}\right]$-acetate into the waxes than are green tissue slices. This increase can not be correlated with the different weights of tissue slices used since the $2.0 \mathrm{~g}$ of yellow tissue is intermediate to the 1.5 and $2.6 \mathrm{~g}$ used in the green control experiments (Table II). The amount incorporated by yellow tissue slices represents $8.7 \%$ of the label fed. The distribution of label among the wax classes from the yellow tissue slices is also very different to that found with the green tissue slices. Only a minor amount of radioactivity was present where the aldehydes were expected to run. Since the Schiffs spray, as in the compositional studies, gave no reaction, we consider that so little aldehyde could have been labelled during the course of the experiment that we have reported the value 0 in Table II. While the proportions of label in the free acids, primary alcohols and esters were all elevated in the yellow tissue wax, we feel the most significant change was the increase in the alkanes. This was an increase from 4 to $54 \times 10^{3} \mathrm{cpm}$. The synthesis of labelled fatty acids by the yellow tissue is of interest since we were unable to isolate free acids from the wax of this tissue (see section 3.1.).

Pre-incubations of the yellow tissue with the lower concentrations of triallate $(0.25$ and 2.5 $\mu \mathrm{mol})$ did not reduce wax synthesis or greatly modify the distribution of label among the wax classes (Table II). This is in marked contrast to the effect of $2.5 \mu \mathrm{mol}$ of triallate on the green tissue described above. A further nine-fold increase in the amount of triallate, however, significantly reduced wax synthesis to $6 \%$ of the control value, and altered the distribution pattern so that it was reasonably similar, excepting for the lack of aldehydes, to that observed after preincubating the green tissue slices with $2.5 \mu \mathrm{mol}$. No labelled alkanes were detected, and more than $60 \%$ of the label was in the free acids.

\subsection{Effects of pre-incubations with $\mathrm{Cl}_{3} \mathrm{AcONa}$ on the ability of green tissue slices to synthesize the members of the wax lipid classes}

Of the small amount of label incorporated into the alkanes by green leaf tissue slices (Table II), the majority was found in the $\mathrm{C}_{31}$ homologue (Table III). Pre-incubation with $2.5 \mu \mathrm{mol}$ of

\section{Table III}

Effects of pre-incubation with $2.5 \mu \mathrm{mol}$ of the sodium salt of trichloroacetic acid on the incorporation of $\left[1-{ }^{14} \mathrm{C}\right]$-acetate into the various epicuticular wax components by green tissue slices $\left(\mathrm{cpm} \times 10^{-2}\right)$.

\begin{tabular}{|c|c|c|c|c|c|c|c|c|c|c|c|c|}
\hline \multirow{2}{*}{$\begin{array}{l}\text { Chain } \\
\text { length }\end{array}$} & \multicolumn{2}{|c|}{ Alkanes } & \multicolumn{2}{|c|}{ Aldehydes } & \multicolumn{2}{|c|}{ Primary alcohols } & \multicolumn{2}{|c|}{ Ester alcohols } & \multicolumn{2}{|c|}{ Ester acids } & \multicolumn{2}{|c|}{ Free acids } \\
\hline & Control & $\mathrm{Cl}_{3} \mathrm{AcONa}$ & Control & $\mathrm{Cl}_{3} \mathrm{AcONa}$ & Control & $\mathrm{Cl}_{3} \mathrm{ACONa}$ & Control & $\mathrm{Cl}_{3} \mathrm{AcONa}$ & Control & $\mathrm{Cl}_{3} \mathrm{AcONa}$ & Control & $\mathrm{Cl}_{3} \mathrm{ACONa}$ \\
\hline 18 & & & 6 & 5 & & & & & 8 & 13 & 32 & 22 \\
\hline 20 & & & 6 & 10 & & & 10 & 16 & 17 & 22 & 37 & 24 \\
\hline 22 & & & 3 & 56 & & & 7 & 23 & 107 & 109 & 199 & 124 \\
\hline 24 & & & 56 & 122 & & & 12 & 27 & 200 & 160 & 365 & 260 \\
\hline 26 & & & 124 & 118 & 34 & & 10 & 18 & 155 & 126 & 337 & 250 \\
\hline 27 & $\operatorname{tr}^{\mathrm{a})}$ & & & & & & & & & & & \\
\hline 28 & & & 87 & 110 & 64 & 109 & 20 & 42 & 49 & 91 & 180 & 183 \\
\hline 29 & 5 & 5 & & & & & & & & & & \\
\hline 30 & & & 430 & 432 & 423 & 643 & 117 & 245 & 75 & 105 & 313 & 224 \\
\hline 31 & 29 & 15 & & & & & & & & & & \\
\hline 32 & & & 5543 & 1570 & 3247 & 1257 & 782 & 346 & 73 & 32 & 606 & 91 \\
\hline 33 & 7 & 1 & & & & & & & & & & \\
\hline
\end{tabular}

a) $\operatorname{tr}=$ trace, $<50$ cpm per single incorporation experiment. see section 2 . 
$\mathrm{Cl}_{3} \mathrm{AcONa}$ resulted in a decrease of label in the $\mathrm{C}_{33}$ and $\mathrm{C}_{31}$ chain lengths. Whether this is a significant decrease is questionable as relatively few cpm $(2,000)$ are involved. In both the aldehydes and primary alcohols, the $\mathrm{C}_{32}$ homologue has most of the label (approx. 87\%). Although the pre-incubation with $\mathrm{Cl}_{3} \mathrm{AcONa}$ resulted in marked decreases in synthesis of the $\mathrm{C}_{32}$ homologues, this chain length still dominated both distributions ( 65 and $63 \%$, respectively). The concomitant increases of $\mathrm{cpm}$ in the $\mathrm{C}_{22}$ and $\mathrm{C}_{24}$ aldehydes $\left(1.2 \times 10^{4}\right)$ and $\mathrm{C}_{28}$ and $\mathrm{C}_{30}$ primary alcohols $\left(2.7 \times 10^{4}\right)$ are very small by comparison to the decrease of label in the $\mathrm{C}_{32}$ homologues $\left(39.7 \times 10^{4}\right.$, and $20.0 \times 10^{4}$, respectively).

Among the ester alcohol moieties, that with 32 carbons has the most label (Table III). Preincubation with $\mathrm{Cl}_{3} \mathrm{AcONa}$ reduced by $56 \%$ the amount of label in the $\mathrm{C}_{32}$ ester alcohol and resulted in a small increase of all the other homologues. This response resembles that of the free primary alcohols. The $\mathrm{C}_{22}, \mathrm{C}_{24}$ and $\mathrm{C}_{26}$ ester acid moieties were all more heavily labelled than the $\mathrm{C}_{32}$ homologue. If the reduction of label in the $\mathrm{C}_{32}$ and $\mathrm{C}_{24}$ chains and increase in that in the $\mathrm{C}_{30}$ and $\mathrm{C}_{28}$ chains after pre-incubation with
$\mathrm{Cl}_{3} \mathrm{AcONa}$ are significant is questionable. The most nearly uniform distribution of label among the various chain lengths of a lipid class occurred in the free acids. Although more cpm were present in the $\mathrm{C}_{32}$ homologue than in the other chain lengths, they represent only $29 \%$ of the total. The inhibitory effect of $\mathrm{Cl}_{3} \mathrm{AcONa}$ was most marked on the $\mathrm{C}_{32}$ homologue (approx. $85 \%$ reduction) although, excepting $\mathrm{C}_{28}$, all other chain lengths also incorporated less label.

A comparison of the chain length distributions within the various wax classes (Table I) with that of the pattern of label incorporated into these chains (Table III) reveals that in some cases such as the primary alcohols a fairly good resemblance exists. In other lipid classes such as the free acids, the two types of spectra are quite different. This is a further indication that wax synthesis by tissue slices is not identical to that in the intact plant leaves.

\subsection{Effects of pre-incubations with triallate on the ability of yellow tissue slices to synthesize the components of the wax lipid classes}

Yellow tissue slices (Table IV) incorporated label into more and shorter alkane chains $\left(\mathrm{C}_{23}\right.$ to

\section{Table IV}

Effects of pre-incubations with triallate on the incorporation of $\left[1-{ }^{14} \mathrm{C}\right]$-acetate into three wax classes by yellow tissue slices $\left(\mathrm{cpm} \times 10^{-2}\right)$.

\begin{tabular}{|c|c|c|c|c|c|c|c|c|c|c|}
\hline \multirow{3}{*}{$\begin{array}{l}\text { Chain } \\
\text { length }\end{array}$} & \multicolumn{3}{|c|}{ Alkanes } & \multicolumn{4}{|c|}{ Primary alcohols } & \multicolumn{3}{|c|}{ Free acids } \\
\hline & \multirow{2}{*}{ Control } & \multicolumn{2}{|c|}{ Triallate $(\mu \mathrm{mol})$} & \multirow{2}{*}{ Control } & \multicolumn{3}{|c|}{ Triallate $(\mu \mathrm{mol})$} & \multirow{2}{*}{ Control } & \multicolumn{2}{|c|}{ Triallate $(\mu \mathrm{mol})$} \\
\hline & & 0.25 & 2.50 & & 0.25 & 2.50 & 25.0 & & 0.25 & 2.50 \\
\hline 18 & & & & & & & & 248 & 228 & 72 \\
\hline 20 & & & & & & & 7 & 753 & 877 & 414 \\
\hline 21 & 4 & 28 & 14 & & & & & & & \\
\hline 22 & & & & & & & 20 & 1350 & 1708 & 1354 \\
\hline 23 & 135 & 182 & 126 & & & & & & & \\
\hline 24 & & & & 557 & 67 & 302 & 47 & 1720 & 1826 & 1751 \\
\hline 25 & 88 & 107 & 80 & & & & & & & \\
\hline 26 & & & & 887 & 168 & 491 & 48 & 947 & 1105 & 1450 \\
\hline 27 & 104 & 115 & 89 & & & & & & & \\
\hline 28 & & & & 728 & 253 & 750 & 88 & 766 & 1114 & 1609 \\
\hline 29 & 165 & 149 & 107 & & & & & & & \\
\hline 30 & & & & 2478 & 1693 & 2958 & 345 & 766 & 1242 & 1266 \\
\hline 31 & 48 & 43 & 25 & & & & & & & \\
\hline 32 & & & & 6719 & 6241 & 4123 & 265 & 168 & 1032 & 48 \\
\hline 33 & & 9 & & & & & & & & \\
\hline
\end{tabular}


Table V

Effects of pre-incubations with triallate on the incorporation of $[1-14 \mathrm{C}]$-acetate into the various ester acids and ester alcohols by yellow tissue slices $\left(\mathrm{cpm} \times 10^{-2}\right)$.

\begin{tabular}{|c|c|c|c|c|c|c|}
\hline \multirow{3}{*}{$\begin{array}{l}\text { Chain } \\
\text { length }\end{array}$} & \multicolumn{3}{|c|}{ Ester acids } & \multicolumn{3}{|c|}{ Ester alcohols } \\
\hline & \multirow{2}{*}{ Control } & \multicolumn{2}{|c|}{ Triallate $(\mu \mathrm{mol})$} & \multirow{2}{*}{ Control } & \multicolumn{2}{|c|}{ Triallate $(\mu \mathrm{mol})$} \\
\hline & & 0.25 & 2.50 & & 0.25 & 2.50 \\
\hline 18 & 213 & 145 & 395 & & & 31 \\
\hline 20 & 1006 & 783 & 1626 & 670 & 773 & 345 \\
\hline 22 & 1421 & 1007 & 1695 & 520 & 580 & 432 \\
\hline 24 & 953 & 794 & 350 & 1378 & 1489 & 900 \\
\hline 26 & 287 & 430 & & 619 & 575 & 443 \\
\hline 28 & & 166 & & 154 & 330 & 201 \\
\hline 30 & & 173 & & 455 & 391 & 664 \\
\hline 32 & & & & 890 & 575 & 392 \\
\hline
\end{tabular}

$\mathrm{C}_{29}$ ) than did the green tissue slices (Table III). This result parallels the observation that the alkanes on yellow leaf tissue are composed of more and shorter homologues than those on green tissue. When pre-incubated with 0.25 $\mu \mathrm{mol}$ of triallate a slightly increased amount of label was found in the shorter homologues. After treatment with $2.5 \mu \mathrm{mol}$ of triallate, synthesis of the longer chains was somewhat reduced and that of the shorter chains unchanged compared to the control (Table IV).

The yellow tissue slices synthesized the same primary alcohols as did the green ones, but the dominance of the $\mathrm{C}_{32}$ homologue was less pronounced being only $59 \%$ of the total (Table IV). Pre-incubation with $0.25 \mu \mathrm{mol}$ of triallate strangely had relatively little effect on incorporation of label into the $\mathrm{C}_{32}$ homologue, but it significantly reduced that into all the other chains. Increase of the triallate concentration to $2.5 \mu \mathrm{mol}$ reduced synthesis of the $\mathrm{C}_{32}$ chains by $39 \%$ compared to the control, while $25 \mu \mathrm{mol}$ reduced it by $96 \%$. The $4 \%$ synthesized, however, was $26,500 \mathrm{cpm}$. The latter concentration of triallate also resulted in a very strong reduction of label incorporation into the other primary alcohols.

The data in Table IV also reveal that yellow tissue slices can synthesize all the even chain fatty acids having from 18 to 32 carbons. The $\mathrm{C}_{22}$ and $\mathrm{C}_{24}$ homologues had the most label, while the $\mathrm{C}_{32}$ homologue had the least. Since free acids were not isolated from yellow leaf tissue, this infers that the specific activity of the fatty acids synthesized from $\left[1-{ }^{14} \mathrm{C}\right]$-acetate must be quite high. Using the method of NETTING and BARR (36), an estimate can be obtained of the minimal specific activity of, for example, the $\mathrm{C}_{24}$ free fatty acid as its methyl ester isolated from the yellow tissue slices after pre-treatment with $2.5 \mu \mathrm{mol}$ of triallate. In these calculations the flame ionization detector limit of $0.1 \mu \mathrm{g}(0.26$ nmol) was used, since no mass trace was detectable for the $\mathrm{C}_{24}$ chain length. The specific activity of this acid was deduced to be at least $16,000 \mathrm{dpm} \cdot \mathrm{nmol}^{-1}$.

Pre-treatment with $0.25 \mu \mathrm{mol}$ of triallate increased synthesis of all but the $\mathrm{C}_{18}$ acid (Table IV). The greatest stimulation was of the $\mathrm{C}_{32}$ acid which increased five-fold to $10.3 \times 10^{4} \mathrm{cpm}$. Compared to the control, the higher concentration of triallate markedly depressed synthesis of the $\mathrm{C}_{32}$ acid (only $0.5 \times 10^{4} \mathrm{cpm}$ ), stimulated by $18.4 \times 10^{4} \mathrm{cpm}$ that of the $\mathrm{C}_{26}, \mathrm{C}_{28}$ and $\mathrm{C}_{30}$ acids but did not influence that of the $\mathrm{C}_{22}$ and $\mathrm{C}_{24}$ acids.

The distribution of label among the ester acid moieties isolated from the yellow leaf tissue is shown in Table $\mathrm{V}$. The $\mathrm{C}_{20}, \mathrm{C}_{22}$ and $\mathrm{C}_{24}$ chains are most heavily labelled. Pre-incubation with $0.25 \mu \mathrm{mol}$ of triallate resulted in some decrease of label in the $\mathrm{C}_{24}$ and shorter chains plus some increase in $\mathrm{C}_{26}, \mathrm{C}_{28}$ and $\mathrm{C}_{30}$ chains. The opposite was observed with $2.5 \mu \mathrm{mol}$ of triallate. The 
synthesis of the $\mathrm{C}_{22}$ and shorter homologues was greater than in the absence of triallate while that of the $\mathrm{C}_{24}$ and longer ones was less. Good incorporation of $\left[1-{ }^{14} \mathrm{C}\right]$-acetate occurred into all the even ester alcohol homologues from $\mathrm{C}_{18}$ to $\mathrm{C}_{32}$ (Table V). The $\mathrm{C}_{24}$ chain had the most label $\left(13.8 \times 10^{4} \mathrm{cpm}\right)$, the $\mathrm{C}_{28}$ chain the least $\left(1.5 \times 10^{4} \mathrm{cpm}\right)$. This radioactivity distribution pattern (Table $\mathrm{V}$ ) is far more similar to the appropriate mass distribution pattern of the ester alcohols (Table I), than is that of the ester alcohols synthesized by the green tissue slices (Table III) to the appropriate mass distribution pattern (Table I). Pre-incubation with $0.25 \mu \mathrm{mol}$ triallate depressed synthesis of $\mathrm{C}_{32}$ chains by $35 \%$, but had relatively little effect on the other chain lengths (Table V). The higher concentration of triallate $(2.5 \mu \mathrm{mol})$ decreased incorporation of label into all ester alcohols except $\mathrm{C}_{28}$ and $\mathrm{C}_{30}$ which had a little more label $\left(2.6 \times 10^{4} \mathrm{cpm}\right)$ than they did in the control experiment. This response of the ester alcohols is similar to that observed with the free primary alcohols (Table IV).

\section{DISCUSSION}

That light can influence the structure of wax bodies on cuticular surfaces was first shown by JUNIPER in 1959 (18). He transferred dark grown pea seedlings to full or reduced light intensity environments and followed the resulting development of the wax bodies. More recent exploitation and extension of the same basic approach with other species have demonstrated that the light effect manifests itself differently from species to species. To illustrate, the minimal light intensity required for formation of the characteristic wax coating on leaf surfaces grown in full light has been found to range from as little as $20 \%$ full sunlight in several Eucalyptus species (12) to more than $60 \%$ of full glass house light in Brassica napus (44). Furthermore, in Brassica oleracea, which has several basic wax structure types, higher light intensities were found, especially in the mutants studied, to favor formation of one structural type (1). When grown in the absence of light, pea leaves have very little defined wax structure, whereas barley seedling leaves are densely covered by wax bodies $(18,19$, P. vON WETtSTEIN-KNOWLES unpubl.). In the present study, advantage was taken of the normal development process experienced by maize leaves in which the tissue passes from a yellow to a green stage. The almost total lack of wax structures on the yellow tissue surface was replaced by the expected characteristic wax coating over the green tissue surface. While the data clearly demonstrate that light is instrumental in wax body formation, it remains to be determined which biochemical processes require light. In the following discussion we will present our results on the wax biosynthetic capacities of the yellow and green maize leaf tissues as well as the influence of two inhibitors on these capacities.

\subsection{Light and fatty acyl elongation}

Relatively few comparisons of the effect of light on wax class composition have been made. The largest effect reported was the absence of secondary alcohols on dark grown Pisum leaves which amounted to $7 \%$ of the wax on light grown leaves (31). In B. oleracea a reduced light intensity was found under most temperature and relative humidity regimes to have little effect on wax class composition (1). Furthermore, when an effect was noted in the wild type it was generally not paralleled in the four investigated mutants. Wax from dark grown barley seedlings was found to have an almost identical wax class distribution to that of light grown ones (11). In our present studies, in which we did not attempt to quantitate the wax classes, the lipid class composition of the waxes from the two types of tissue were quite different. That is, aldehydes occurred in trace amounts and free acids were. not detectable in the wax from the yellow tissue. Primary alcohols dominated the green but not the yellow tissue wax. Alkanes were an important component of yellow but not green tissue wax. From the combined results we conclude that illumination can be required to form specific wax lipid classes.

In all earlier in vitro studies of the effect of light on the biosynthesis of wax classes, tissue slices were prepared from light grown leaf tissue, and then incubated with labelled precursors in the dark or under varying light intensities (21, $23,29,35)$. Such studies are expected to reveal whether placing light grown tissue in the dark 
can modify a biosynthetic pathway already proceeding in the tissue. The most interesting results are those of $M_{A C E Y}(29)$ working with B. oleracea. The tissue slices incorporated less acetate into the wax in the dark than in the light, but they incorporated equal amounts of palmitate under both conditions. Light incubated tissue directed substantially more label from both precursors into the hydrocarbons, somewhat more into the secondary alcohols, but considerably less into the esters than did the dark incubated tissue. Furthermore, the specific activity of the hydrocarbons, secondary alcohols and ketones synthesized in the light was greater than that in the dark, while the reverse was true for the aldehydes and the free fatty acids. In the present study, we looked for an effect of light on wax class composition by comparing tissues at very different developmental stages. That is, we compared the biosynthetic capabilities under relatively low light intensity of tissue slices from normally developing yellow segments and light exposed green segments of the fifth leaf. Our results revealed marked differences in the distribution of label among the wax classes from the two types of tissues which on the whole paralleled those for the in vivo wax composition. That is, while $40 \%$ of the label was incorporated by green tissue slices into the aldehydes, none was found in this wax class in the incubations with the yellow tissue. Instead relatively more label was incorporated by the yellow tissue into the alkanes, primary alcohols and free acids. Interestingly, labelled free acids could be isolated from both the yellow and green tissue slice experiments. The combined results suggest that light plays a role in conditioning leaf tissue to produce a certain wax class composition, and at least in the maize leaf, this role can be investigated in the described in vitro system.

The marked stimulatory effect of light on aldehyde and primary alcohol synthesis is interesting in connection with the biosynthetic origin of these wax classes. Considerable evidence points to aldehydes often being precursors of the primary alcohols $(27,32)$. Strong support for this conclusion comes from the recent analysis of the maize mutant $\mathrm{g} / .5$ which is blocked in formation of the normally dominating primary alcohols. Instead aldehydes accumulate forming $84 \%$ of the total wax (5). Thus the observed presence versus essential absence of aldehydes in the two types of tissue can be interpreted as follows. When relatively little fatty acyl precursor is available, it is reduced all the way to the primary alcohol (yellow tissue). When much precursor is available, the rate of reduction of the fatty acyl chains to aldehydes is greater than that of their subsequent reduction to primary alcohols with the resulting appearance of aldehydes in the wax (green tissue).

Two reports investigate the effect of light on the homologue composition within wax classes. The more detailed of these was the analysis of the wax on dark and light grown barley seedling leaves (11). The data revealed that on the light grown leaves one chain length or group of chain lengths dominated each wax class, whereas on the dark grown leaves two prominent chain lengths or groups thereof occurred. Except for the free fatty acids, the longer chain length or group thereof dominated in the light grown tissue. The major chain length of the two groups differed by two or more carbons. A comparison of the alkane distributions on light and dark grown Pisum leaves gave analogous results (31). In the present analyses a similar prominence of shorter homologues was observed in the alkanes, esters and both ester moieties from the yellow tissue. The chain length spectra for the aldehydes and primary alcohols from the two tissue types were not distinguishable by this criterion, however. In the case of the aldehydes, this comparison is perhaps not very useful since only trace amounts are present in the yellow tissue wax.

On the other hand when tissue slices were fed acetate, the resulting homologue distributions for all the investigated yellow tissue wax fractions were characterized by significant increases of the shorter homologues. Results for the odd chain components (only alkanes which account for $2 \%$ or less of the wax) can be seen by comparing the first columns in Tables III and IV. Table VI presents the total amount synthesized by the green and yellow tissues of each even chain length homologue having 18 to 32 carbons. In wax from the green tissue, label in the $\mathrm{C}_{32}$ homologues accounted for $75 \%(8,415$ pmol) of the total synthesis, whereas in the yellow tissue it represented only $29 \% \quad(6,384$ pmol) of the total synthesis. The aldehydes and 
Table VI

Effects of pre-incubations with inhibitors on the synthesis of the even chain length epicuticular wax components from $[1-14 \mathrm{C}]$-acetate by green and yellow tissue slices from the fifth leaf of maizea).

\begin{tabular}{|c|c|c|c|c|c|c|c|c|}
\hline \multirow[b]{2}{*}{$\begin{array}{l}\text { Chain } \\
\text { length }\end{array}$} & \multicolumn{3}{|c|}{ Green } & \multicolumn{5}{|c|}{ Yellow } \\
\hline & Control & $\begin{array}{l}\mathrm{Cl}_{3} \mathrm{AcONa} \\
(2.5 \mu \mathrm{mol})\end{array}$ & $(\%)^{b)}$ & Control & $\begin{array}{c}\text { Triallate } \\
(0.25 \mu \mathrm{mol})\end{array}$ & (\%) & $\begin{array}{l}\text { Triallate } \\
(2.5 \mu \mathrm{mol})\end{array}$ & (\%) \\
\hline 18 & 38 & 33 & (87) & 378 & 306 & $(81)$ & 409 & (108) \\
\hline 20 & 57 & 59 & $(104)$ & 1994 & 1997 & $(100)$ & 1958 & (98) \\
\hline 22 & 259 & 256 & (99) & 2702 & 2705 & $(100)$ & 2858 & (106) \\
\hline 24 & 520 & 467 & $(90)$ & 3784 & 3428 & (91) & 2712 & (72) \\
\hline 26 & 542 & 420 & $(77)$ & 2249 & 1870 & (83) & 1957 & (87) \\
\hline 28 & 328 & 439 & $(134)$ & 1353 & 1529 & $(113)$ & 2102 & (155) \\
\hline 30 & 1114 & 1354 & $(122)$ & 3037 & 2872 & (95) & 4013 & (132) \\
\hline \multirow[t]{2}{*}{32} & 8415 & 2706 & $(32)$ & 6384 & 6443 & $(101)$ & 3746 & (59) \\
\hline & 11273 & 5734 & $(51)$ & 21881 & 21150 & (97) & 19755 & (90) \\
\hline
\end{tabular}

a) Results are expressed as pmol incorporated. The values were calculated from the observed cpm incorporated by using the counting efficiency of $93 \%$ and the specific activity of the $\left[1-{ }^{14} \mathrm{C}\right]$-acetate of $59 \mathrm{mCi} \cdot \mathrm{mmol}^{-1}$. Esters were analyzed as their acid and alcohol moieties.

b) $\mathrm{pmol}$ in presence of inhibitor/pmol in absence of inhibitor $\times 100$

alcohols contributed most to the total in the green tissue wax, while only the alcohols were a major contributor in the yellow tissue wax. All the other chain lengths, however, were more actively synthesized by the yellow than the green tissue. In fact, as the chain length decreased from 30 to 20 carbons, the relative synthesizing ability of the yellow tissue compared to the green increased from 2- to 34-fold. The wax components making the largest contributions to the total synthesis of the $\mathrm{C}_{20}$ to $\mathrm{C}_{26}$ chains in the yellow tissue were the free acids and the two ester moieties. In the green tissue only the two types of acids contributed significantly to the total amount of these shorter chain lengths synthesized.

Two other interesting points are brought out by the data in Table VI. Firstly, relatively little of the $\mathrm{C}_{28}$ chain length was utilized by either tissue type. This suggests that $C_{28}$ chains were more readily elongated than used by an associated wax pathway. Secondly, the yellow tissue synthesized approx. two times as many fatty acyl chains as did the green tissue. In some respects this was an unexpected observation. The rate of wax synthesis in $\mu \mathrm{g} \cdot \mathrm{cm}^{-1}$ in 24 hours by light grown barley seedlings was found to be 15 compared to a rate of 6 by dark grown ones (11). When the dark grown seedlings were transferred to the light the rate increased to an average of 46 in the first 24 hours. The maximum synthesis took place only after a lag of about 8 hours. Furthermore, dark grown seedling leaves of rye grass (7), for example, incorporated only one sixth the amount of acetate into total fatty acyl chains as did tissue slices from light grown leaves of the same age. In barley the ability of tissue slices from dark grown seedling leaves to incorporate acetate into total fatty acyl chains decreased as the age of the leaves increased (15). Our findings can be reconciled with the earlier results if the presently used normally developing yellow tissue is in fact already primed for wax synthesis. That is, either the green tissue supplies all the necessary factors to the yellow tissue or the latter has been exposed to a very low level of light which has induced the necessary factors.

The different amounts of the fatty acyl chains synthesized by the two tissue types noted above is also of interest in connection with the following earlier observations on total lipid acyl synthesis. Firstly, the distribution of label among the acyl chains after incubation of tissue slices from dark grown barley seedlings in the light 
and dark was compared (15). In the dark incubated tissue, nearly half of the label was reported present in $\mathrm{C}_{24}$ and $\mathrm{C}_{26}$ chains (the longest detected), whereas in the light incubated tissue only a fifth of the label was in the same chain lengths. Secondly, successive transverse sections of seven day old light grown maize leaves were prepared after removing the coleoptile and first leaf (14). The tissue slices from the yellow basal segments incorporated 40 to $50 \%$ of the label into $\mathrm{C}_{22}$ to $\mathrm{C}_{26}$ chains (again the longest detected), whereas those from the green tip segments incorporated $9 \%$ into these chain lengths under low light intensity and only $1 \%$ under high light intensity. Especially under high light the tip segments utilized the acetate for synthesis of the shorter and unsaturated fatty acyl chains characteristic of the chloroplast lipids.

It is tempting to try to correlate the results just cited with the present maize and earlier barley (11) wax observations. Both mesophyll and epidermal cells in tissue slices from yellow or dark grown tissue appear to synthesize considerable amounts of $\mathrm{C}_{20}$ to $\mathrm{C}_{26}$ chains. Those in the mesophyll cells end up as part of complex lipids whereas those in the epidermal cells enter the wax and perhaps also complex lipids. By comparison, in greened or greening tissue, the mesophyll cells are restricted primarily to a production of fatty acids for the chloroplast lipids while the epidermal cells develop a specific system for the synthesis of the very long wax acyl chains. This reasoning explains the increased prominence of shorter homologues characteristic for the wax classes arising from the decarboxylation and reductive pathways on dark grown barley seedling leaves. Likewise, the presence of the shorter homologues in all the wax classes synthesized by tissue slices prepared from the yellow maize leaf segments is accounted for. When the in vivo composition of the wax fractions from the yellow and green maize tissue were compared, however, only the chain length spectra of the alkanes, esters and moieties thereof exhibited the expected difference. The homologue distributions for the aldehydes and primary alcohols from the two types of maize tissue were indistinguishable by this criterion. Why should this be when the acetate incorporation patterns differed? Given that the yellow tissue, as mentioned above, is exposed to a very low light intensity plus the fact that in normal green maize leaf tissue primary alcohols are far more actively synthesized than are the other wax classes, one is led to the following proposal. Activation of the long chain primary alcohol synthetic machinery requires a lower light intensity than activation of the machinery for the other wax classes. In the in vitro tissue slice system, the level of the light induced product is decreased beneath that necessary to activate the primary alcohol synthetic machinery.

\subsection{Inhibitors and fatty acyl elongation}

The effect of $\mathrm{Cl}_{3} \mathrm{AcONa}$ on wax synthesis has been examined in a number of plant systems $(8$, $21,23,24,26,30,32,38)$. Initial studies with intact leaves of $B$. oleracea revealed that $\mathrm{Cl}_{3} \mathrm{AcONa}$ concentrations up to $5 \mu \mathrm{mol} /$ leaf inhibited incorporation of acetate into hydrocarbons, secondary alcohols and ketones much more severely than that into primary alcohols. free fatty acids and esters (21). In tissue slices from $\mathrm{B}$. oleracea, $\mathrm{Cl}_{3} \mathrm{AcONa}$ was later shown (30) to inhibit incorporation of acetate into the $\mathrm{C}_{29}$ and $\mathrm{C}_{30}$ homologues of the investigated wax classes by $37 \%$. Simultaneously small amounts of label accumulated in the $\mathrm{C}_{26}$ fatty acid. While an approx. $30 \%$ inhibition of alcohols and esters was noted, the effect on the distribution of label among the homologues was not investigated The results from a complete analysis of the effect of $\mathrm{Cl}_{3} \mathrm{AcONa}$ on the incorporation of acetate into intact spikes of Hordeum vulgare confirmed the Brassica tissue slice observations (32, J. D. MikKelsen unpubl.). That is, while synthesis of the seven wax fractions is rather similarly inhibited by $0.6 \mu \mathrm{mol}$ (ranging from 27-72\%), the synthesis of the longest chain length derivatives within each wax class, in this case $\mathrm{C}_{30}, \mathrm{C}_{31}$ and $\mathrm{C}_{32}$, was most severely blocked. The most convincing study demonstrating that $\mathrm{Cl}_{3} \mathrm{AcONa}$ inhibits the terminal elongation steps was carried out on tissue slices from Vicia faba petals (26). Stearic acid labelled the three major in vivo alkanes, $C_{27}, C_{29}$ and $C_{31}$, as well as a $C_{33}$ homologue. Addition of $5-20 \mu \mathrm{mol}$ of $\mathrm{Cl}_{3} \mathrm{AcONa}$ inhibited the synthesis of the alkanes by $46-95 \%$, respectively. The synthesis of the longest two was impeded the most. The tissue 
slices were also able to elongate and/or decarboxylate octacosanoic and triacosanoic acids. Upon addition of $\mathrm{Cl}_{3} \mathrm{AcONa}$, only the elongation of the labelled precursor was inhibited. In the present study with green maize tissue slices, treatment with $\mathrm{Cl}_{3} \mathrm{AcONa}$ resulted in a reduction by 5,709 pmol of the synthesis of the $C_{32}$ chains, a small increase of 351 pmol in the $\mathrm{C}_{28}$ and $\mathrm{C}_{30}$ chains, but had no marked affect on the synthesis of the shorter chains when compared to the control (Table VI). The question can be asked why in this instance a specific block in only one elongation step $\left(C_{30}\right.$ to $\left.C_{32}\right)$ occurred, whereas in the above mentioned studies two or more of the final elongation steps were sensitive to $\mathrm{Cl}_{3} \mathrm{AcONa}$. At present one can only speculate as to what extent, for example, the experimental systems used or the innate differences in the elongation system(s) within (including the relationship between that in the yellow and green tissue) and between the various plants investigated contribute to the results.

The $\mathrm{Cl}_{3} \mathrm{AcONa}$ appears to have an additional effect on wax synthesis because shorter acyl chains fail to accumulate in significant quantities when the terminal elongation reactions are blocked. This behavior infers that $\mathrm{Cl}_{3} \mathrm{AcONa}$ controls the amount of precursors entering the wax synthesizing machinery. Possibly these two phenotypic affects, inhibition of given elongation steps and control of available precursors, arise from a single initial reaction. Such a case is known for the regulation of the acyl chain length in the mammary gland $(20,28)$. Therein two thioesterases have been shown to terminate elongation, while the level of malonyl-CoA appears to limit the rate of fatty acid synthesis. At increasing concentrations of malonyl-CoA the rate of synthesis is enhanced which decreases the probability of thioesterase II terminating the elongation at one of the medium chain lengths $\left(\mathrm{C}_{8}-\mathrm{C}_{12}\right)$ for which it is specific. This results in an increased synthesis of the longer chains $\left(\mathrm{C}_{14}\right.$ and $\mathrm{C}_{16}$ ) which are terminated by thioesterase $\mathrm{I}$, a component of the fatty acid synthetase multienzyme complex. One wonders whether in the present system the $\mathrm{Cl}_{3} \mathrm{AcONa}$ competes with acetic acid for the available $\mathrm{CoA}$ thus influencing the available malonyl-CoA level. Given the possibility of the existence of several thioesterases, an analogous regulation of the fatty acyl chain length in plant epidermal tissues can be envisaged. On the other hand, it is difficult to reconcile with this proposal the fact that while the yellow maize tissue incorporates twice as much acetate into wax fatty acyl chains as does the green tissue, the shorter chain lengths are more prominent in the wax from the former than the latter tissue. This observation also conflicts with earlier suggestions $(16,21)$ that $\mathrm{Cl}_{3} \mathrm{AcONa}$ acts by inhibiting the synthesis of CoA from pantoic acid. Furthermore, in leaves of Brassica (21) and in germinating seeds of Pisum (13), $\mathrm{Cl}_{3} \mathrm{AcONa}$ does not inhibit synthesis of internal lipids for which malonyl-CoA also serves as the condensing reagent.

Effects of various thiocarbamates on epicuticular waxes have been found in many studies, of which we feel the results from the following two are most pertinent to the present maize results. Application of EPTC as an aqueous soil drench resulted in a $60 \%$ inhibition of wax synthesis by B. oleracea plants. Synthesis of the $\mathrm{C}_{29}$ dominated wax classes was more sensitive than was that of the aldehydes, primary alcohols and free acids, while that of the esters was actually stimulated by $100 \%(10)$. Almost identical results were obtained from tracer studies using $P$. sativum tissue slices (25). That is, Avedex at a one $\mu$ mol concentration inhibited formation of the $C_{31}$ secondary alcohol and hydrocarbon by $50 \%$ and that of the $\mathrm{C}_{26}$ and $\mathrm{C}_{28}$ primary alcohols by $10 \%$, but stimulated synthesis of the esters by $50 \%$. At higher inhibitor concentrations ester synthesis was also blocked, although label accumulated in the $\mathrm{C}_{22}$ ester acid moiety. From these results the conclusion was drawn that thiocarbamates inhibit wax synthesis by interfering with elongation (27), and the suggestion put forth that the different sensitivities of various wax classes was attributable to their formation by different elongation systems. An alternative explanation would be that only one elongation system was involved and that wax classes dominated by longer chains would be inhibited before those dominated by shorter chains. Such an explanation fits in well with the reported inhibition of $\mathrm{C}_{20}$ to $\mathrm{C}_{24}$ chains by EPTC although total lipid synthesis actually increased in germinating pea seeds (13), for example.

In the present study with triallate, ester synthesis was again the least sensitive to the 
inhibitor, although no stimulation was noted at the lowest concentration. We did find, however, with $2.5 \mu \mathrm{mol}$ a small increase of $\mathrm{C}_{20}$ and $\mathrm{C}_{22}$ chains, which interestingly occurred only in the ester acids. As shown in Table VI, in which synthesis of the even chain lengths from all wax classes is summarized, the inhibition of elongation was rather specific for the $\mathrm{C}_{30}$ to $\mathrm{C}_{32}$ step. In contrast to the $\mathrm{Cl}_{3} \mathrm{AcONa}$ results, the inhibition was accompanied by a stimulation of $\mathrm{C}_{28}$ and $\mathrm{C}_{30}$ chains. The latter accounted for $60 \%$ of the decrease in $\mathrm{C}_{32}$ chain synthesis. Since the accumulation of these shorter chains occurred almost entirely in the free acids, it infers that neither the reductive nor decarboxylative pathway can use such large amounts of these chain lengths as precursors. The reductive pathway at least prefers 32 carbon chains over 26,28 or 30 carbon chains in the yellow tissue just as in the green tissue. In the case of the decarboxylative pathway, one can ask whether the accumulated chains are available to the decarboxylative system, that is whether only one elongation system is really involved. One also wonders whether the fact that in vivo the alkanes have three prominent longer homologues is correlated with the observation that synthesis of all three is inhibited by triallate. In order to resolve the problems posed with regard to the number of elongation systems as well as the mode of action of thiocarbamates thereupon, it will be necessary to work with a system in which the decarboxylative and reductive pathway lipid classes are characterized not only by undergoing the same number of elongation steps but also by being present in more equal amounts than they are in maize.

\section{ACKNOWLEDGEMENTS}

We are indebted to M. Petersen for outstanding technical assistance; to Dr. G. Mellerio of the Centro di Spettrometria di massa, Pavia, Italy, for the mass spectra; to A.-S. STeInhol.z and N. RASmussen for preparing the figures; to B. Petersen for looking after the plants; to Professor F. Salamini of the Istituto Sperimentale per la Cerealicoltura, Bergamo, Italy, for the seeds; and to Monsanto Technical Center, Louvain-la-Neuve, Belgium, for the triallate. P. Avato also wishes to acknowledge the helpful, critical discussions with Dr. G. BIANCHI of the Istituto di Chimica Organica, Università di Pavia, Italy.

\section{REFERENCES}

1. BAKER, E. A.: The influence of environment on leaf wax development in Brassica oleracea var. gemmifera. New. Phytol. 73, 955-966 (1974)

2. Bianchi, G.: Genetic control of composition of epicuticular waxes of maize: A survey. Genet. Agr. 33, 75-86 (1979)

3. Bianchi, G., P. Avato \& F. Sal.amini: Glossy mutants of maize VI. Chemical constituents of glossy 2 epicuticular waxes. Maydica 20, 165173 (1975)

4. Bianchi, G., P. Avato \& F. Sal amini: Glossy mutants of maize VII. Chemistry of glossy I, glossy 3 and glossy 7 epicuticular waxes. Maydica 22, 9-17 (1977)

5. Bianchi, G., P. Avato \& F. Sal.amini: Glossy mutants of maize. VIII. Accumulation of fatty aldehydes in surface waxes of $\mathrm{g} / \mathrm{s}$ maize seedlings. Biochem. Genet. 16, 1015-1021 (1978)

6. Bianchi, G., P. Avato \& F. Salamini: Glossy mutants of maize. IX. Chemistry of glossy 4 , glossy 8, glossy 15 and glossy 18 surface waxes. Heredity 42, 39l-395 (1979)

7. Bolton, P. \& J. L. Harwood: Fatty acid synthesis by slices from developing leaves. Planta 138, 223-228 (1978)

8. Buckner, J. S. \& P. E. Kol.Attukudy: Specific inhibition of alkane synthesis with accumulation of very long chain compounds by dithioerythritol, dithiothreitol and mercaptoethanol in Pisum sativum. Arch. Biochem. Biophys. 156, 34-45 (1973)

9. Davis, D. G.: Scanning electron microscopic studies of wax formations on leaves of higher plants. Can. J. Bot. 49, 543-546 (1971)

10. Fiore, J. A. \& M. J. Bukovac: Pesticide effects on the plant cuticle: III. EPTC effects on the qualitative composition of Brassica oleracea $\mathrm{L}$. leaf cuticle. J. Amer. Soc. Hort. Sci. 103, $297-$ 301 (1978)

11. GiESE, B. N.: Effects of light and temperature on the composition of epicuticular wax of barley leaves. Phytochem. 14, 921-929 (1975)

12. Hallam, N. D.: Growth and regeneration of waxes on the leaves of Eucalyptus. Planta 93. 257-268 (1970)

13. Harwood, J. L. \& P. K. Stumpf: Fat metabolism in higher plants. XLIII. Control of fatty acid synthesis in germinating seeds. Arch. Biochem. Biophys. 142, 281-291 (1971) 
14. Hawke, J. C., M. G. Rumsby \& R. M. Leech: Lipid biosynthesis in green leaves of developing maize. Plant Physiol. 53, 555-561 (1974)

15. Hawke, J. C. \& P. K. StumpF: Fat metabolism in higher plants. XXVII. Synthesis of long-chain fatty acids by preparations of Hordeum vulgare L. and other Graminae. Plant Physiol. 40, 1023$1032(1965)$

16. Hilton; J. L., L. L. Jansen \& W. A. Gentner: Beta-alanine protection of yeast growth against the inhibitory action of several chlorinated aliphatic acid herbicides. Plant Physiol. 33, 4345 (1958)

17. Holloway, P. J., G. M. Hunt, E. A. Baker \& M. J. K. MaCEY: Chemical composition and ultrastructure of the epicuticular wax in four mutants of Pisum sativum (L). Chem. Phys. Lipids 20, 141-155 (1977)

18. JUNIPER, B. E.: The surfaces of plants. Endeavour $18,20-25$ (1959)

19. JUNIPER, B. E.: Growth, development, and effect of the environment on the ultra-structure of plant surfaces. J. Linn. Soc. (Bot.) 56, 413-419 (1960)

20. KNUDSEN, J.: Medium-chain fatty acid synthesis in lactating-rabbit mammary gland. Intracellular concentration and specificity of medium-chain acyl thioester hydrolase. Biochem. J. 181, 267274 (1979)

21. Kolattukudy, P. E.: Biosynthesis of wax in Brassica oleracea. Biochem. 4, 1844-1855 (1965)

22. Kol.attukudy, P. E.: Biosynthesis of wax in Brassica oleracea. Relation of fatty acids to wax. Biochem. 5, 2265-2275 (1966)

23. Kolattukudy, P. E.: Biosynthesis of paraffins in Brassica oleracea. Fatty acid elongation-decarboxylation as a plausible pathway. Phytochem. 6, 963-975 (1967)

24. Kolattukudy, P. E.: Further evidence for an elongation-decarboxylation mechanism in the biosynthesis of paraffins in leaves. Plant Physiol. 43, 375-383 (1968)

25. Kolattukudy, P. E. \& L. Brown: Inhibition of cuticular lipid biosynthesis in Pisum sativum by thiocarbamates. Plant Physiol. 53, 903-906 (1974)

26. Kolattukudy, P. E., R. Croteau \& L. Brown: Structure and biosynthesis of cuticular lipids. Hydroxylation of palmitic acid and decarboxylation of $\mathrm{C}_{28} . \mathrm{C}_{30}$ and $\mathrm{C}_{32}$ acids in Vicia faba flowers. Plant Physiol. 54, 670-677 (1974)

27. Kolattukudy, P. E., R. Croteau \& J. S. BUCKNER: Biochemistry of plant waxes. In: Chemistry and Biochemistry of Natural Waxes.
P. E. Kolattukudy, ed., Elsevier, Amsterdam, pp. 289-347 (1976)

28. Libertini, L. J. \& S. Smith: Synthesis of long chain acyl-enzyme thioesters by modified fatty acid synthetases and their hydrolysis by a mammary gland thioesterase. Arch. Biochem. Biophys. 192, 47-60 (1979)

29. MACEY, M. J. K.: The effect of light on wax synthesis in leaves of Brassica oleracea. Phytochem. 9, 757-761 (1970)

30. MACEY, M. J. K.: Wax synthesis in Brassica oleracea as modified by trichloroacetic acid and glossy mutations. Phytochem. 13, 1353-1358 (1974)

31. Macey, M. J. K. \& H. N. Barber: Chemical genetics of wax formation on leaves of Pisum sativum. Phytochem. 9, 5-12 (1970)

32. Mikketsen, J. D.: The effects of inhibitors on the biosynthesis of the long chain lipids with even carbon numbers in barley spike epicuticular wax. Carlsberg Res. Commun. 43, 15-35 (1978)

33. Mikkelsen, J. D.: Structure and biosynthesis of $\beta$-diketones in barley spike epicuticular wax. Carlsberg Res. Commun. 44, 133-147 (1979)

34. Mikkelsen, J. D. \& P. von Wettstein-KnowLES: Biosynthesis of $\beta$-diketones and hydrocarbons in barley spike epicuticular wax. Arch. Biochem. Biophys. 188, 172-181 (1978)

35. Netring, A. G.: Chemical genetics of waxes in plants. Ph. D. Thesis, University of New South Wales, Sydney, Australia (1971)

36. Netting, A. G. \& C. Barr: Design of an accurate and versatile radio gas liquid chromatograph. Anal. Biochem. 84, 136-146 (1978)

37. Netting, A. G. \& P. von Wettstein-Knowles: The physico-chemical basis of leaf wettability in wheat. Planta 114, 289-309 (1973)

38. Soliday, C. L., P. E. Kolattukudy \& R. W. Davis: Chemical and ultrastructural evidence that waxes associated with the suberin polymer constitute the major diffusion barrier to water vapor in potato tuber (Solanum tuberosum L.). Planta 146, 607-614 (1979)

39. Wettstein-KNOWLes, P. von: The molecular phenotypes of the eceriferum mutants. In: Proc. 2nd Int. Barley Genet. Symp. (1969) R. A. Nilan, ed., Pullman, Wash., USA, Washington State Univ. Press, pp. 146-193 (1971)

40. Wettstein-KNowles, P. von: Gene mutation in barley inhibiting the production and use of $\mathrm{C}_{26}$ chains in epicuticular wax formation. FEBS Letters 42, 187-191 (1974)

41. Wettstein-Knowles, P. von: Genetics and biosynthesis of plant epicuticular waxes. In: Advances in the Biochemistry and Physiology of 
Plant Lipids. L. Å. Appelquist \& C. Liljenberg. eds., Elsevier/North Holland Biomedical Press. Amsterdam, pp. 1-26 (1979)

42. Wettstein-Knowles, P. von, P. Avato \& J. D. MiKKelsen: Light promotes synthesis of the very long fatty acyl chains in maize wax. In: Recent Advances in the Biogensis and Function of Plant Lipids, P. Mazliak, ed., Elsevier/North Holland
Biomedical Press, Amsterdam. In press. (1980)

43. Wettstein-Knowles, P. von \& B. Sggaard: The cer-cqu region in barley: Gene cluster or multifunctional gene. Carlsberg Res. Commun. 45. $125-141(1980)$

44. Whitecross, M. I. \& D. J. Armstrong: Environmental effects on epicuticular waxes of Brassica napus L. Aust. J. Bot. 20, 87-95 (1972) 